\title{
Tax System Reform in Ethiopian Revenue and Custom Authority
}

\author{
Fetiya Ahmed Meskerem Legesse \\ Wolaita Sodo University, College Of Business and Economics, Department of Public Administration and \\ Development Management
}

\begin{abstract}
This article reviews tax system reform in Ethiopian revenue and custom authority. In order to gather relevant data different sources of data were used. The collected data include the existing literatures as well as statistical reports, magazines, newsletters, manuals, guidelines and organizational documents. . The primary purpose of taxation is to mobilize the revenue required to finance public goods and services. Since taxes have a pervasive influence on economic decisions of individuals and businesses, and on social equity, the tax system should achieve the appropriate level of revenue as efficiently and fairly as possible. Thus a well-designed tax system should be effective in raising revenue, efficient in its effects on economic decisions of households and businesses, and equitable in its impact on different groups in society.
\end{abstract}

Keywords: Tax, Tax system, Tax system reform

DOI: 10.7176/PPAR/9-5-01

Publication date:May $31^{\text {st }} 2019$

\section{INTRODUCTION}

In Ethiopia the year 1991 marked the end of the previous policy regime of hard control that had lasted for nearly two decades. This was the year when the seventeen-year old 'socialist' regime was toppled by the coalition of rebel forces, In contrast to the previous policy regime of hard control; EPRDF initiated a wide range of reforms that covered not only the tax system but also the exchange rate, interest rates, trade, domestic production and distribution. The Ethiopian Revolution Democratic Front (EPRDF), which formed the current government. Starting from 1992, the EPRDF has initiated a wide range of reforms that can be termed as liberalization (AlemayehuGeda and AbebeShimeles 2005).

In Ethiopia, public sector reform initiatives evolved in the late 1990s and early 2000s in response to pervasive institutional weaknesses and capacity deficits across the public sector. A Public Sector Reform Programme (PSCAP) in place managed by the Ministry for Capacity Building. Some of the reforms are Civil Service Reform, District Level Decentralisation, Justice Systems Reform, Urban Management Capacity Building, Tax Systems Reform and Information Communications Technologies. A major part of this programme is a tax reform programme to which a Customs reform component was included in 2003. The reform programme to date has resulted in rationalization of tariff rates, reduction in documentary requirements, simplification of procedures and computerization. This has achieved a dramatic reduction in clearance times, an increase in revenue collection and the elimination of systemic corruption.

In July 2008, as part of the on-going reform, there was a merger of three already existing bodies, the Ministry of Revenue, Ethiopian Customs Authority (ECuA) and the Federal Inland Revenue Authority. The merger resulted in the creation of the Ethiopian Revenue and Customs Agency (ERCA). The Authority has the main responsibility of revenue collection on behalf of the Federal Government of Ethiopia as well as to secure and facilitate legitimate trade. The Authority works closely with the federal police, standardization authority, Ministry of Health and Immigration Service and with other stakeholders.

\section{OVER VIEW OF TAX SYSTEM REFORM IN ETHIOPIA}

Tax reform is one of the major reforms undertaken by the government since the Ethiopian Peoples' Revolutionary Democratic Front came to power in May 1991. Tax rate and tariff reductions, overhauling the tax system and improving tax administration and the modernization of the tax structure were among the core elements of the tax reform.

Recent tax reforms have tended to focus on achieving broader based taxation at more uniform rates and reductions in the level of tax-induced distortions that are prompted by high rates (Rao). Many tax reforms represent an effort by governments to use tax policy as an instrument to promote investment and development, and to address gender issues as well as assisting disadvantaged groups of society (Amin Abedella 2010).

In addition the Government modernizes the tax and custom administration by over hauling the legislations and improving administration. The reform measures are intended to encourage trade, investment and hence development; broadening the tax base and increase Government revenues to support social programs and alleviate poverty; strengthen the enforcement capacity of the tax and customs authorities; and promoting equity in the tax system. The tax reform consists of six projects Theses are

1. Tax Policy and Legislation Project, 
2. Tax Payer Identification (TIN) Project,

3. Presumptive Tax Project

4. Value Added Tax Project

5. Reorganization and Work Producer Development

6. Taxpayers Education Project

Except the first project, the other projects are dealing with the Tax Administration Reform. The responsible body for implementing tax system reform in Ethiopia is Ethiopian revenue and custom authority (ERCA).

\subsection{Rational for the need of the reform}

According to Ethiopian revenue and custom authoritythere are to two main reasons for the need of tax reform. These are external challenge and internal challenge facing ERCA.

Those External Challenges Facing ERCA; Global environment was changing rapidly

$>$ Government needed more revenue to fund National Plans \& Infrastructure

$>$ Low taxpayer compliance levels

> Customs is moving from control to trade facilitation - Customs Revenues are reducing.

$>$ Domestic Taxes needed to contribute a bigger proportion of national taxes.

$>$ Low effective utilization of ICT.

$>$ Clients demanded private sector standards;

$>$ Multiple stakeholders with disparate needs!

$>$ Low levels of Integrity and high corruption levels and

> The government overall economic and political reform to established developmental state

Internal Challenges Facing ERCA; Corruption was extremely high!!

$>\quad$ Low levels of staff skills and competences

$>$ Poor Planning and implementation framework

$>$ Low level of revenue collection( both domestic and customs tax)

$>$ Poor customer handling

$>$ Low enforcement capacity and auditing coverage

$>$ Poor research development capacity

> Poor-coordination at organizational as well as departmental level

> Complicated hierarchical levels

$>$ Low level of trade facilitation

$>$ Poor resource utilization and

$>$ Poor performance monitoring and evaluation.

\subsection{Existing tax reforms}

Since the coming to power of the EPRDF, tax reform has gone through several stages. The first stage (1992/931995/96) took the form of piecemeal changes. The second stage of the tax reform program (1996/97-2000/01) was expanded in scale and breadth, and brought major changes in the tax system. The third stage (2001/022005/2006) was the period for implementation of the studies undertaken during the second stage and improvement in the tax administration. The fourth stage (2006/07 on) has introduced SIGTAS (Standard Integrated Government Tax Administration System) and Business Process Re-engineering (BPR) as part of the efforts to enhance the efficiency of the tax administration. The recent tax administration reforms include the issuance of a unique identification number known as a TIN (Taxpayer Identification Number). Every person having a tax obligation is required to obtain a TIN. In order to address the problems in the implementation of TIN where a single person could have multiple TIN numbers, the tax authority introduced a biometric finger print system so as to deter taxpayers from having multiple TINs.

Tax policy should be guided by the general principles of neutrality, equity, and simplicity. Recent attempts at tax reform have given due consideration to tax preferences such as incentives, credits, tax reliefs, tax holidays, exemptions, deductions and special treatments. On the other hand, some tax reformists argue that such tax preferences and subsidies may push small businesses into the informal sector due to the exceptional treatment given to large or well-connected businesses (Ramalho). Instead, tax credits and investment allowances (with suitable safeguards to minimize dangers), and accelerated depreciation are preferred instruments of advanced tax policies. There is an increasing trend towards the abolition of tax exemptions/privileges from tax laws and their replacement with reduced tax rates or the application of $\mathrm{fl}$ at tax rates.(Amin Abedella, 2010).

Recent tax reforms in Ethiopia have tended to focus on achieving broader based taxation at more uniform rates and reductions in the level of tax-induced distortions that are prompted by high rates (Rao). Many tax reforms represent an effort by governments to use tax policy as an instrument to promote investment and development, and to address gender issues as well as assisting disadvantaged groups of society(ibid).

Taxes can be levied either on income or expenditure (consumption), or on a combination of the two. One of 
the major elements of the Ethiopian tax reform has been the introduction of Value-Added Tax (VAT), which is a consumption tax.

\subsection{Indicative Achievements Made}

In order to tackle the both internal and external challenges ERCA have been taken different measures. These measures are: implementation of tax system reform and implementing the management tool of BPR. Since the launch of the reform and up to the end so many activities had been made which resulted in several output in both on the domestic tax and customs.

\section{Reforms Made On the Customs Side:}

As indicated by the authority there are out comes in custom side. Some of them are customs IT environment has migrated to ASYCUDA++, RevisedCustoms administration and clearanceprocedure, Capacity building in different area, an anti-smuggling manual and strategy has been developed.

\section{Reforms Made On Domestic Tax Side:}

The other output which are resulted by the reform includes: An overhauled income andtax proclamation was introduced, VAT introduced/replace the sales tax, Establishment of large tax payer office, Excise tax proclamation which has been rationalized to more accurately the current business, National implementation of the TIN/SYGTAX system, Finger print system implementation has been launched, New systems, operating manuals and procedures have been implemented, Organizational structures were revised and at last Introduction of presumptive tax schemes

\section{In Addition Some Indicative Achievements Made:}

Like Revenues significantly growth from9.7 billion (2005) to 19.3 billion birr (2008), Customer service somehow improved (including service giving time), new professionals injected to the working system are some of the achievement made in reform implementation.

In order to implement the reform though out ERCA the following strategic initiatives arealso set:

Table 2.1 Prioritized Strategic initiatives of ERCA

\begin{tabular}{|c|c|c|}
\hline$\overline{N o}$ & Rank & Strategic Initiatives \\
\hline 1 & 1 & Implementation of risk management system (on going) \\
\hline 2 & 1 & Develop and implement anti-corruption strategy (New) \\
\hline 3 & 3 & Implement Balanced score card performance measurement system (New) \\
\hline 4 & 4 & Develop and implement Information system improvement project (on going) \\
\hline 5 & 5 & Implement information technology expansion project (on going) \\
\hline 6 & 5 & Implement team working capacity building project (New) \\
\hline 7 & 7 & $\begin{array}{l}\text { Conduct training and education need assessment and develop and implement human } \\
\text { resource development program (on going) }\end{array}$ \\
\hline 8 & 8 & $\begin{array}{l}\text { Strengthen and Implement the tax administration system in well-coordinated manner } \\
(\mathrm{New})\end{array}$ \\
\hline 9 & 9 & Strengthen and Implement Custom clearance procedures (New) \\
\hline 10 & 10 & Develop and implement duty free and tax holyday administration system (New) \\
\hline 11 & 10 & $\begin{array}{l}\text { Conduct study about the implementation of tax laws } \mathrm{b} / \mathrm{n} \text { federal and Regional } \\
\text { Government and develop strategy in order to harmonize the tax laws (New) }\end{array}$ \\
\hline 12 & 12 & Develop and implement total quality management system (New) \\
\hline 13 & 13 & Conduct tax potential study (New) \\
\hline 14 & 14 & Develop and implement resource mobilization and utilization strategy (New) \\
\hline 15 & 15 & Craft and implement employee safety protection strategy (New) \\
\hline 16 & 16 & Conduct customer satisfaction survey (New) \\
\hline 17 & 17 & Identify taxpayer education methods and deliver appropriate education (New) \\
\hline 18 & 17 & Establish and open new tax collection centers (New) \\
\hline 19 & 19 & Implement Authorized economic operators working system (New) \\
\hline 20 & 19 & Develop and implement $3^{\text {rd }}$ party tax collection system (New) \\
\hline
\end{tabular}

These are some of the strategy measure that is taken place in Ethiopian revenue and custom authority for successful implementation of the reform but it is shown that all the strategies are new and only some of them are undergoing strategy which needs carful investigation.

\subsection{Weakness Of The Reform}

Ethiopia, like most countries in Africa, has been making considerable efforts in recent years to restructure its tax system with a view to increase tax revenue as well as reduce distortions in the economy. The impact these reforms have had on the poor is of considerable importance to policymakers, given that the poor and the vulnerable constitute a significant majority of the population in Ethiopia. However, to analyses the distributional 
impact of its tax system is not so straightforward. There are several reasons for this. First, tax evasion is considered to be substantial in Ethiopia, leading to unintentional consequences on income distribution. Second, a substantial portion of tax revenue comes from commodity taxes whose effect on income distribution is essentially determined by household consumption patterns and the market structure. Thus, disentangling the effect of the tax system per se on income distribution from the distortions arising out of tax administration and market imperfections becomes difficult. The third factor is the paucity of data that are needed to analyses the welfare effects of tax reform: this lack extends to social accounting matrices, and sufficient rounds of household income and expenditure surveys(AlemayehuGeda and AbebeShimeles2005).

In addition Even ifthe tax reform program enabled the sector to be in better position as compared to use the authority detected that it could not bring: Institutional transformation and Meet international standards. The tax system is neither fair nor equitable and it lacks transparency; The tax system does not minimize noncompliance, it increases compliance costs, and in cases of dispute the appeal process is excessively long, The available tax privileges are not favourable , The tax reform impedes production, favouring certain sectors at the expense of others, The tax base is too narrow and the burden of taxation falls excessively on larger, formal businesses, Tax administration is inefficient, arbitrary and relies heavily on coercion, penalties and imprisonment; penalties for minor transgressions are disproportionately high, The tax administration is not effective in collection, has not developed a strategy for collecting taxes and has shifted the costs of collection onto the private sector, Service and support to taxpayers service is grossly inadequate, and public- private dialogue has been insufficient and The VAT administration and compliance system is not well designed and VAT has created economic distortions amongst VAT registered and non-registered taxpayers.

\subsection{Major achievement in public services delivery}

From the previous discussion one can observe that some of the projects of the tax reform Programs are still at project level. Moreover, some of the measurers need time to see their Impact on the tax collection. However, one can see the trends that can indicate the likely Output of the reform measures. The tax reform measures output can be measured in two ways.First, by looking at the trends of real value of Government tax revenue and secondly, by Looking at the changes in the structure of the tax revenue. Moreover, though the VAT has implemented for one and a quarter of a year, comparative analysis of VAT income with the sales tax income will be made to evaluate the VAT project. (DemirewGetachew, 2011)

Tax reform in Ethiopia as a reform has a series of initiatives across the public service that focuses on improving efficiency in service delivery, in addition to building accountability and responsiveness to citizens for meeting service standards. Transparency and accountability have also improved since the reform started and Tax reforms are based onwhat are usually referred to as the "Four Rs";

- Raising revenue,

- Redistribution of wealth,

- Re-pricing to discourage consumption and/or to address externalities, and

- Representation to make clear accountability and good governance.

TheEthiopian Custom Authority has achieved remarkable improvements in servicedelivery. For instance, prior to prior to the introduction of the new service delivery system, importers were forced to pass 74 workprocesses and the process took about 59days to clear import declaration. This long process cut down to 10 workprocesses sand the process has taken only a day. Moreover, a new window opened to provide efficient services to exporter and new manual and procedures were developed for tax assessment, auditing and tax collection

\subsection{Implementation deficit of the tax reform}

During the implementation of the reform deficits haven observed. As noted by the ERCA the reason behind for such deficit is Employee and customers resistance to go along with the reform, Lack of experience to manage reform, Shortage of skilled man power in tax and customarea to run the reform, Lackreform demission to go along with international standards, Resourcesshortage, Lack of well communication and coordination and not ably to out fromrotten activities

\subsection{Lesson learned from South Africa tax reform}

Taxes in South Africa increasingly have a focus on political and economic developmental demands. important lessons from the experience of south Africa with taxation and tax reform are that the tax system reform should aim at not taxing the poor (rather than trying to level down the income of the rich) and that tax policy has a special role to play in generating revenue for development, a role which it should endeavour fill in a neutral way (HonourableTrevor, 2002).In addition our country reformers learn from south Africa tax reform include ; tax reform process must be well coordinated, Tax reform must take into account the initial conditions at home and abroad ,Attention has to be paid to the preparation and analysis of reforms, with broad consultation, providing a reasonable period of adjustment prior to implementation and ensuring consistency of the reform measures , 
Changes in tax system must be presented as part of longer term strategy to improve the public sector environment for the private sector, The base of existing taxes should be broadened. Base broadening can increase revenues and improve the simplicity, neutrality and equity of the tax system, The use of the tax system for special tax preferences/incentives should be approached with great care, in order to avoid unintended consequences and/ or abuse, The self-assessment procedure should be encouraged to increase compliance ,Persuasion of taxpayers should take precedence over coercion. The majorities of taxpayers are willing to comply voluntarily but may require help. Strong enforcement measures (litigation, search and seizure, penalties, interest on uncollected tax, etc.) should be reserved for cases of severe malpractice and finally take severe action when deliberate tax evasion is detected.

\section{CONCLUSION}

The primary purpose of taxation is to mobilize the revenue required to finance public goods and services. Since taxes have a pervasive influence on economic decisions of individuals and businesses, and on social equity, the tax system should achieve the appropriate level of revenue as efficiently and fairly as possible. Thus a welldesigned tax system should be effective in raising revenue, efficient in its effects on economic decisions of households and businesses, and equitable in its impact on different groups in society. The reform programme to date has resulted in rationalization of tariff rates, reduction in documentary requirements, simplification of procedures and computerization. This has achieved a dramatic reduction in clearance times, an increase in revenue collection and the elimination of systemic corruption.

One of the major elements of the Ethiopian tax reform has been the introduction of Value-Added Tax (VAT), which is a consumption tax.

Tax reform in Ethiopia as a reform has a series of initiatives across the public service that focuses on improving efficiency in service delivery, in addition to building accountability and responsiveness to citizens for meeting service standards. Transparency and accountability have also improved since the reform started

These are some of the strategy measure that is taken place in Ethiopian revenue and custom authority for successful implementation of the reform like balanced score card business processing and total quality management but it is shown that all the strategies are new and only some of them are undergoing strategy which needs carful investigation.

\section{Recommendation}

In order to improve tax administration efficiency, the countries need tointroduce electronic filing and payment system. If properly implemented and adopted by businesses, electronic tax systems speed up processing, improve data collection and reduce error rates. This option is only available where the telecommunications infrastructure is in place to support it.

Encouragement rather than coercion. The overwhelming majority of taxpayers, whilst not being enthusiastic about paying tax, recognise that it is their civic duty to do so. The tax administration system should take this as its starting point and concentrate primarily on helping people to get their tax affairs right rather than threatening them if they get them wrong. The rights of the taxpayers have to be respected. Taxpayers should be treated properly and in accordance with the law and the constitution by tax authorities. Decisions on tax issues must be rendered quickly and these decisions should be implemented without delay. Build their capacities to keep adequate records, not just for tax purposes but to help them run their businesses better.

\section{REFERENCES}

Geda, Alemayehu\&Shimeles, Abebe, 2005."Taxes and Tax Reform in Ethiopia, 1990-2003," WIDER Working Paper Series 065, World Institute for Development Economic Research (UNU-WIDER).

Amin Abdella (2010); The Impact of Tax Reform on Private Sector development ; producedand distributed by Addis Ababa Chamber of Commerce and SectorialAssociationswithfinancial support from the Swedish Agency for International DevelopmentCooperation, Sida.

DemirewGetachew (2011) Tax Reform In Ethiopia \& Progress To Date Paper Presented on the Ethiopian Economic Association Sound International Conference on the Ethiopian Economy June 3 - 4, 2004 Addis Ababa.

Honourable Trevor A Manuel,(2002) The South African Tax Reform Experience Since1994;Address by the MP, Minister of Finance Annual Conference of The International Bar Association.

MalebogoBakwena1(2012); The Recent Economic Reforms In South Africa : A critical assessment; Botswana Journal of African Studies Vol. 26, No. 1, Issue \# 46. 